\title{
Reproductive patterns of blacktail comber (Serranus atricauda, Serranidae) from south-west Portugal seamounts
}

\author{
Ana Neves • Vera Sequeira • Rafaela Barros Paiva • \\ Ana Rita Vieira • Leonel Serrano Gordo
}

Received: 29 April 2013/Revised: 24 September 2013/Accepted: 17 October 2013/Published online: 6 November 2013

(C) Springer-Verlag Berlin Heidelberg and AWI 2013

\begin{abstract}
The knowledge of the reproductive strategy is essential for the comprehensive understanding of the population dynamics of any fish species. This study intends to define the spawning season, verify the type of fecundity regulation and estimate relative annual fecundity for Serranus atricauda inhabiting the south-west of Portugal seamounts (Gorringe, Ampère and Lion). Monthly samples, between September 2010 and December 2011, were obtained from commercial vessels. This species is synchronously hermaphroditic, and mature individuals were found all year round, with gonadosomatic index peak from February to September. No clear relation between hepatosomatic index and Fulton's condition factor and gonadal development was found, and therefore, it is probable that reproductive success depends more on environmental conditions and food availability during the spawning season than on body energy reserves. No gap exists between pre-vitellogenic and vitellogenic oocytes and the oocyte size-frequency distribution during the main spawning season show no dominant cohort progressing through time. The number of standing stock of advanced vitellogenic oocytes showed an increase trend along the spawning season decreasing only at its end and the relative
\end{abstract}

Communicated by A. Malzahn.

A. Neves $(\bowtie) \cdot$ V. Sequeira $\cdot$ R. B. Paiva ·

A. R. Vieira - L. S. Gordo

Centro de Oceanografia, Faculdade de Ciências, Universidade de

Lisboa, Campo Grande, 1749-016 Lisbon, Portugal

e-mail: ananeves73@gmail.com

R. B. Paiva · A. R. Vieira - L. S. Gordo

Departamento de Biologia Animal, Faculdade de Ciências,

Universidade de Lisboa, Campo Grande,

1749-016 Lisbon, Portugal intensity of $\alpha$-atresia was always low throughout this period with an increase towards the end. All these criteria corroborate the indeterminate fecundity type assigned to $S$. atricauda in previous studies. Mean relative annual fecundity estimated was $5,655 \pm 4,321$ oocytes per gram of gutted weight.

Keywords Reproductive strategy - Indeterminate fecundity $\cdot$ Serranus atricauda $\cdot$ Seamounts $\cdot$ Portugal

\section{Introduction}

Knowledge of reproductive strategy is essential for a comprehensive understanding of the population dynamics of any fish species (Hilborn and Walters 1992). Knowledge of individual fecundity is an important parameter to estimate the total egg production of a fish stock. This allows to evaluate the stock reproductive potential (SRP) and might be important for recruitment studies (Murua et al. 2003).

The knowledge of fecundity pattern of a fish stock is of great importance in fisheries biology since it determines the method of choice for estimating the fecundity of individuals and the total egg production of populations as well as the egg production method that should be devised for the assessment of the spawning biomass (Ganias 2013). Two types of fecundity have been identified: determinate fecundity where it is assumed that fecundity is fixed before the onset of spawning, and indeterminate fecundity where a continuous recruitment of oocytes into vitellogenesis during the spawning season occurs and therefore, fecundity is not fixed before the onset of spawning (Hunter et al. 1992; Murua et al. 2003). Indeterminate fecundity is usually associated with asynchronous oocyte development meaning that no dominant cohort can be seen in the oocyte- 
frequency distribution until hydration occurs (SaboridoRey and Murua 2003).

Species with indeterminate fecundity depend not only on the maternal attributes (e.g. age, size and condition) but also on environmental conditions (Murua and Motos 2006). In these species, feeding conditions will greatly influence spawning activity and the rate of recruitment of pre-vitellogenic oocytes into the stock of yolked ooyctes (Rinchard and Kestenmont 2003).

Blacktail comber, Serranus atricauda (Günther 1874) is a species whose distribution extends from the Bay of Biscay (north-eastern Atlantic) southward to Mauritania and around the Azores, Madeira and Canaries archipelagos, the Mediterranean coast of Morocco, Algeria, southern Spain, and occasionally southern France (Tortonese 1986). It lives on rocky bottoms, from the shallow subtidal down to about $150 \mathrm{~m}$ depth (García-Díaz et al. 2006). It is an important commercial species with increasing landings in Portuguese ports, from near 4 ton in 2005 to 22.6 ton in 2011 (DGRM 2012) which are due to an increase in the longline fleet effort that seasonally operates in the southwest Portugal seamounts.

It belongs to the Serranidae family, one of the few groups, with only other Serranidae genus, Hypoplectrus (Puebla et al. 2011) and one Muraenidae genus, Siderea (Fishelson 1992), that present a synchronous hermaphroditism with male and female tissues simultaneous functional in the gonads (García-Díaz et al. 2002). Serranus atricauda is a fish species reported as having indeterminate fecundity (García-Díaz et al. 2006). However, this assumption was only based on indirect evidence such as the absence of a gap between primary and secondary growth stages' oocytes diameter. Nevertheless, this evidence is also present in species with determinate fecundity, e.g., Scomber scombrus (Greer Walker et al. 1994) or Trisopterus luscus (Alonso-Fernández et al. 2008). Therefore, other lines of evidence are necessary to accurately ascertain the fecundity type of a species, e.g., the seasonal variation in percentage and number of different oocyte stages, the seasonal variation in mean diameter of tertiary vitellogenic oocytes and the incidence of atresia during the spawning season (Murua and Saborido-Rey 2003).

Before commencing any routine study on fish reproduction, detailed investigation of the dynamics of oocyte growth, maturation and egg production should be undertaken for the population in question, since these reproductive traits are highly adaptive (Murua et al. 2003). Therefore, this study intends to elucidate the reproductive biology of $S$. atricauda in Portuguese waters since little information exists on hermaphrodite species in general and this species in particular. Our main goals will be focusing on: (1) the histological ovotestis structure; (2) the characterization of the spawning season; (3) the definition of the fecundity type (indeterminate or determine) based on the main factors related to oocyte development and recruitment; and (4) the estimation of fecundity. This information will be fundamental for understanding the reproductive potential of this stock.

\section{Materials and methods}

\section{Sampling}

Monthly samples were obtained between September 2010 and December 2011 from commercial vessels operating on the seamounts south-west of Portugal (Gorringe, Ampère and Lion) (Fig. 1). Total length (TL, to the nearest $0.1 \mathrm{~cm}$ ), gutted weight (W, to the nearest $0.1 \mathrm{~g}$ ) and gonad and liver weight (GW and LW, respectively, to the nearest $0.01 \mathrm{~g}$ ) were recorded in the laboratory for each fish. All gonads were removed and preserved in a $10 \%$ buffered formaldehyde solution. Slices were taken, dehydrated with ethanol and embedded in metacrylate, and histological sections (3-5 $\mu \mathrm{m})$ were cut from each slice, stained with toluidine blue and digitized using a visual image analysis system (Leica DFC 290).

\section{Ovotestis structure and classification of maturity stages}

For histological classification of the maturity stages of both gender, two slides for each gonad were prepared, one of the anterior region of the gonad where male and female tissue were present and another from the middle region with only female tissue.

To characterize each stage of oogenesis and spermatogenesis digitized images of histological sections were obtained with a magnification of $200 \times$ for female cells and $400 \times$ for male cells. Only oocytes with a visible nucleus were measured for maximum and minimum diameter and averaged afterwards, in order to decrease the variance caused by the histological processing. Measurements were performed on 500 oocytes and 700 male cells using the software package Image-Pro Plus.

Histological classification of the gonads was based on the development stage of the most advanced cellular type, and maturity stages were assigned according to BrownPeterson et al. (2011).

\section{Spawning season characterization}

After the characterization of each maturity stage, their monthly frequency was investigated in order to determine the spawning season of $S$. atricauda. This analysis was further corroborated with the monthly evolution of the gonadosomatic index $(\mathrm{GSI}=(\mathrm{GW} / \mathrm{W}) \times 100)$. Bioenergetic 
Fig. 1 Sampling area location in the north-east Atlantic Ocean

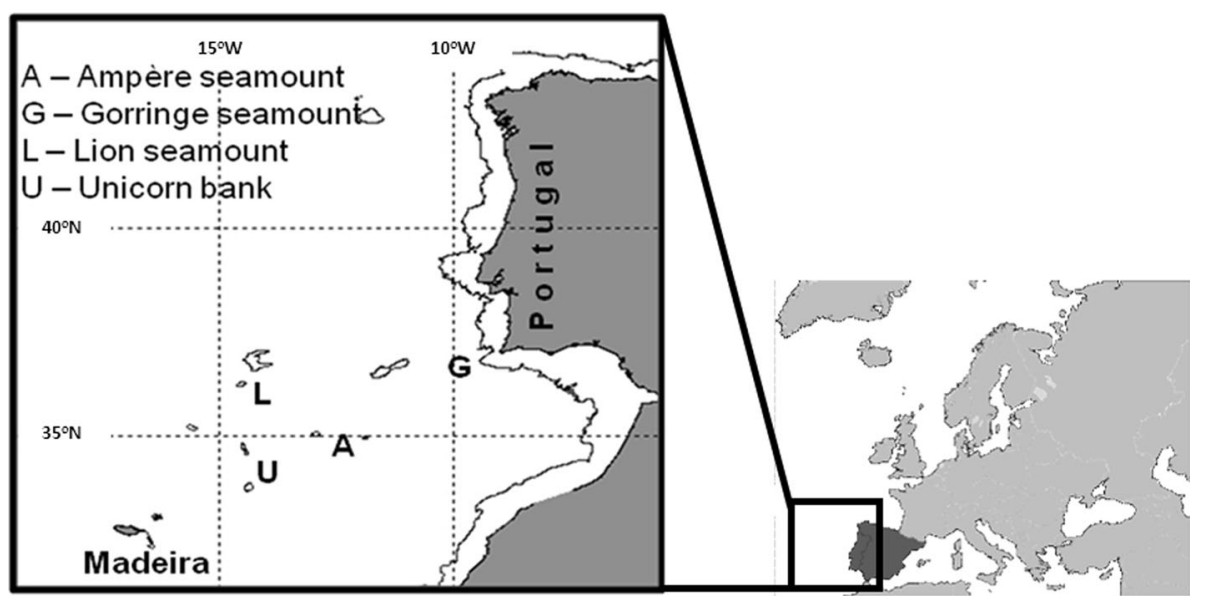

indices were assessed through the hepatosomatic index $(\mathrm{HIS}=(\mathrm{LW} / \mathrm{W}) \times 100)$ and the Fulton's condition factor $\left(K=\left(\mathrm{W} / \mathrm{TL}^{3}\right) \times 100\right)$ to analyse the fish condition. Simple regression analysis was used to investigate relationships between GSI with HSI and $K$.

\section{Fecundity-type definition}

In the present study, the four lines of evidence suggested by Hunter et al. (1992), Greer Walker et al. (1994) and Murua and Saborido-Rey (2003) were investigated, namely (1) presence of an hiatus between pre-vitellogenic and vitellogenic oocytes; (2) size-frequency distribution of the advanced vitellogenic oocyte standing stock over the spawning season; (3) number of standing stock of advanced vitellogenic oocytes over the spawning season; and (4) the relative intensity of atresia over the spawning season. Digitized images of histological sections for five individuals per month during the spawning season (TL ranging between 34.2 and $44.3 \mathrm{~cm}$ ) were analysed. The stereometric method (Emerson et al., 1990) was used to estimate the abundance of each type of normal and atretic oocytes, being approximately 100 oocytes per individual measured using the software package Image-Pro Plus. Relative intensity of atresia, as percentage of $\alpha$-atretic yolked oocytes in relation to total number of yolked oocytes (Grande et al. 2012), was also estimated for these individuals.

\section{Fecundity estimation}

To estimate the annual fecundity, for species with indeterminate fecundity, the number of oocytes spawned per batch, the percentage of females spawning per day (spawning fraction) and the duration of the spawning season are required parameters (Hunter et al. 1985; Murua and Saborido-Rey 2003).

Batch fecundity was estimated using the gravimetric method. Histological sections were examined to select ovaries containing hydrated oocytes and no signs of new post-ovulatory follicles (POF). The presence of these follicles would indicate that spawning had already begun, and thus, batch fecundity would be underestimated. Five individuals per month, with the characteristics mentioned above, were selected. From each ovary, five subsamples of approximately $0.25 \mathrm{~g}$ were analysed. Each sample was placed in a Petri dish; oocytes were separated using a needle and hydrated oocytes were counted under a stereomicroscope with $6 \times$ magnification. Relative batch fecundity was estimated as the number of oocytes per gram of individual.

Monthly spawning fraction was calculated as the number of actively spawning females divided by the total number of mature active females (developing phase with the exception of the early subphase and spawning capable phase including actively spawning subphase) in each sample date (Alonso-Fernández et al. 2011). Spawning frequency was estimated as the inverse of spawning fraction (Murua et al. 2003).

Spawning season was estimated as the number of days between the first and last occurrence of individuals with hydrated oocytes.

Relative annual fecundity estimates were obtained as the product of relative batch fecundity by spawning fraction by the duration of spawning season.

\section{Results}

A total of 299 individuals ranging from 27.0 to $46.3 \mathrm{~cm}$ in TL were sampled during this study.

Ovotestis structure and classification of maturity stages

Analysis of gonad organization and development confirmed that $S$. atricauda is a synchronously hermaphroditic species with ovary and testis present in all individuals and 


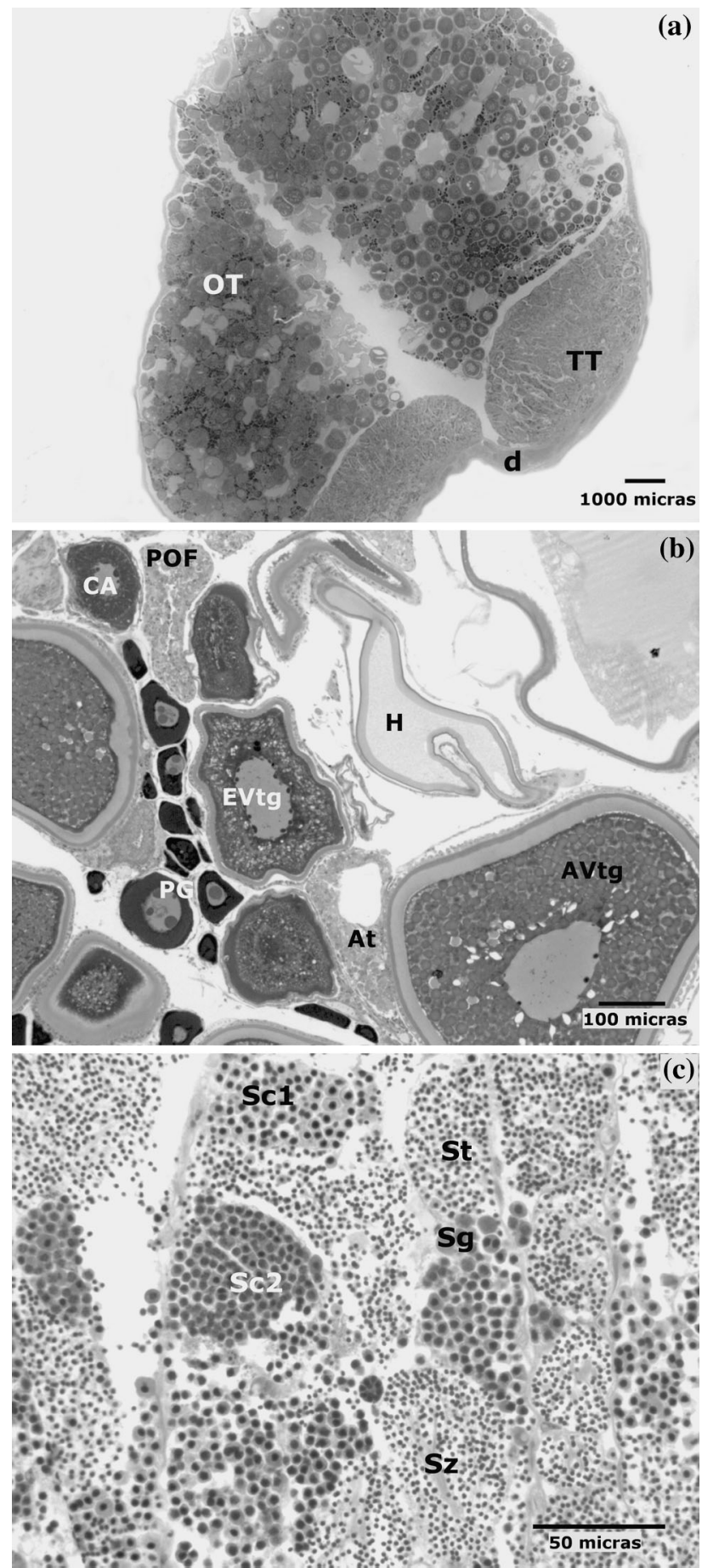

Fig. 2 Transverse section of gonads of Serranus atricauda: a functional ovotestis (OT ovarian tissue, TT testicular tissue, $d$ duct), b detail of functional ovarian tissue (At atresia, AVtg advanced vitellogenic oocyte, $C A$ cortical alveoli oocyte, EVtg early vitellogenic oocyte, $H$ hydrated oocyte, $P G$ primary growth oocyte, $P O F$ post-ovulatory follicle), c detail of functional testicular tissue ( $\mathrm{Scl}$ primary spermatocytes, $S c 2$ secondary spermatocytes, $S g$ spermatogonia, St spermatids, $S z$ spermatozoa)
Table 1 Summary of oocyte growth stages defined for Serranus atricauda

\begin{tabular}{|c|c|c|}
\hline $\begin{array}{l}\text { Oocyte } \\
\text { development } \\
\text { stage }\end{array}$ & Description & Diameter $(\mu \mathrm{m})$ \\
\hline $\begin{array}{c}\text { Primary growth } \\
\text { oocytes (PG) }\end{array}$ & $\begin{array}{l}\text { Polyhedral with a large } \\
\text { nucleus where several } \\
\text { nucleoli can easily be } \\
\text { observed }\end{array}$ & $24-100(58.5 \pm 18.3)$ \\
\hline $\begin{array}{l}\text { Cortical } \\
\text { alveolar stage } \\
\text { (CA) }\end{array}$ & $\begin{array}{l}\text { Cortical alveoli and } \\
\text { lipids appear in the } \\
\text { cytoplasm }\end{array}$ & $86-238(149 \pm 36)$ \\
\hline $\begin{array}{l}\text { Early } \\
\text { vitellogenesis } \\
\text { stage (EVtg) }\end{array}$ & $\begin{array}{l}\text { Corresponds to Vtg1 and } \\
\text { Vtg2 oocytes in Brown- } \\
\text { Peterson et al. (2011) } \\
\text { study, is characterized } \\
\text { by the appearance of } \\
\text { yolk proteins }\end{array}$ & $134-397(254 \pm 54)$ \\
\hline $\begin{array}{l}\text { Advanced } \\
\text { vitellogenesis } \\
\text { stage (AVtg) }\end{array}$ & $\begin{array}{l}\text { Yolk cytoplasmatic } \\
\text { inclusions enlarge and } \\
\text { lipidic droplets } \\
\text { surround the nucleus } \\
\text { corresponds to Vtg } 3 \\
\text { oocytes in Brown- } \\
\text { Peterson et al. (2011) } \\
\text { study }\end{array}$ & $286-571(431 \pm 72)$ \\
\hline $\begin{array}{l}\text { Oocyte } \\
\text { maturation } \\
(\mathrm{OM})\end{array}$ & $\begin{array}{l}\text { Nucleus migrates, the } \\
\text { yolk granules and lipids } \\
\text { fuse to form a } \\
\text { continuous mass }\end{array}$ & $397-620(529 \pm 47)$ \\
\hline $\begin{array}{l}\text { Hydrated } \\
\text { oocytes }(\mathrm{H})\end{array}$ & $\begin{array}{l}\text { These oocytes are ready } \\
\text { to be released. They } \\
\text { have a homogeneous } \\
\text { appearance and tend to } \\
\text { lose their shape during } \\
\text { the histological process, } \\
\text { and therefore, their } \\
\text { dimensions are difficult } \\
\text { to access }\end{array}$ & $738-957(845 \pm 51)$ \\
\hline
\end{tabular}

A brief description of each stage and the range size, mean and standard deviation in brackets of the oocytes are given

maturing at the same time (Fig. 2a). The ovotestis consists in two lobes of elliptic shape which are fused posteriorly. The male tissue occupies only a small part of the gonad in a ventrolateral position in the anterior region of the ovotestis. As individuals become mature, the testis turns longer and wider occupying a larger region in the ovotestis, but rarely exceeds half of the lobe length.

The oocyte development undergoes multiplication, growth and maturation events which can be summarized in four major stages: primary growth, cortical alveoli, vitellogenesis and maturation (Wallace and Selman 1981; Selman and Wallace 1986; Tyler and Sumpter 1996). In this species, the oocyte development is asynchronous, showing 
Table 2 Summary of male cells stages defined for Serranus atricauda

\begin{tabular}{|c|c|c|}
\hline Male cells stage & Description & Diameter $(\mu \mathrm{m})$ \\
\hline $\begin{array}{l}\text { Spermatogonia } \\
\quad(\mathrm{Sg})\end{array}$ & $\begin{array}{l}\text { They appear either } \\
\text { single or in small } \\
\text { groups and have } \\
\text { round shape with a } \\
\text { conspicuous } \\
\text { cytoplasm and a } \\
\text { prominent central } \\
\text { nucleus }\end{array}$ & $6.53-12.04(8.41 \pm 1.14)$ \\
\hline $\begin{array}{l}\text { Primary } \\
\text { spermatocysts } \\
(\mathrm{Sc} 1)\end{array}$ & $\begin{array}{l}\text { Always appear } \\
\text { enclosed in cysts }\end{array}$ & $3.67-5.77(4.47 \pm 0.41)$ \\
\hline $\begin{array}{l}\text { Secondary } \\
\text { spermatocysts } \\
(\mathrm{Sc} 2)\end{array}$ & $\begin{array}{l}\text { Very similar to Sc1 } \\
\text { but smaller }\end{array}$ & $2.45-4.19(3.16 \pm 0.34)$ \\
\hline Spermatids (St) & $\begin{array}{l}\text { Even smaller than } \\
\text { Sc2 but still found } \\
\text { enclosed in cysts }\end{array}$ & $1.54-2.69(2.04 \pm 0.22)$ \\
\hline $\begin{array}{l}\text { Spermatozoids } \\
\quad(\mathrm{Sz})\end{array}$ & $\begin{array}{l}\text { They present cilia and } \\
\text { are free in the } \\
\text { lumen }\end{array}$ & $1.47-2.31(1.87 \pm 0.17)$ \\
\hline
\end{tabular}

A brief description of each stage and the range size, mean and standard deviation in brackets of the cells are given

a continuous oocyte diameter distribution among the different phases of development with all stages present in mature phase (Fig. 2b; Table 1).

The testicular tissue of $S$. atricauda is organized into lobules that consist on many seminiferous tubules containing cysts. Each cyst is formed by spermatogenic cells in the same stage of development and bounded by a thin layer of connective tissue.

Following the terminology of Grier (1981), five stages of cells could be observed in the cross section of the testis (Fig. 2c; Table 2).

\section{Spawning season characterization}

From the sampled individuals, $80 \%$ contained ovaries in a spawning capable/actively spawning stage and $89 \%$ testes in a spawning capable stage. Spawning capable/actively spawning individuals occurred all year around. Individuals with spawning capable testes were dominant in all months with exception of December 2010. Individuals with spawning capable/actively spawning ovaries were dominant from February to September with values near to $100 \%$ (Fig. 3). Developing individuals were mainly observed in November and December (being the dominant stage in ovaries in these 2 months) while regressing and regenerating stages were mostly observed between October and December. Male and female tissues showed synchronized maturity phases although a slight asynchrony could be observed in some individuals.
GSI showed higher values from February to September, with two peaks in June (5.0) and September (4.3) whereas $K$ and HSI showed higher values from October to December and February, respectively, with a decrease in $K$ during spawning months while HSI followed the GSI pattern from June to September (Fig. 4). Relationship of GSI with HSI and with $K$ showed that GSI was significantly related to HSI $\left(r^{2}=0.1889, p<0.01\right)$ but not to $K(p=0.7432)$. However, the determination coefficient was too low to consider that GSI and HSI were strongly correlated.

Fecundity-type definition

Fecundity type was analysed under the four criteria mentioned in the "Materials and methods" section. No hiatus exists between pre-vitellogenic and vitellogenic oocytes except for the formation of the hydrated oocytes group that will be shed in the next batch (oocyte diameter $>700 \mu \mathrm{m}$ ) (Fig. 5); furthermore, no dominant cohort progressing through time was evident in the oocyte size-frequency distribution of $S$. atricauda during the main spawning season (Fig. 5). Regarding the third line of evidence, we analysed the number of both all secondary growth oocytes (Fig. 6a) and advanced oocytes only (Fig. 6b). In both cases, an increasing trend along the spawning season was observed. Only in the last month of spawning, a decrease in oocyte numbers was observed, reaching values similar to that at the beginning of the spawning season. Finally, the relative intensity of $\alpha$-atresia was always low through the spawning season with an increase towards the end (Fig. 7).

\section{Fecundity estimation}

Absolute batch fecundity ranged between 1,413 and 85,445 hydrated oocytes throughout the spawning season. A slight relation between total length and gutted weight was observed (Fig. 8). Relative batch fecundity varied between 5 and 93 oocytes per gram of gutted weight with an average of 22. Spawning occurred daily, with estimates of spawning frequency along the spawning season varying between 1 and 1.25 days. Considering the spawning season from February to October, the relative annual fecundity varied between 1,175 and 23,809 oocytes per gram of gutted weight with a mean of $5,655 \pm 4,321$ oocytes $\mathrm{g}^{-1} \mathrm{GW}$.

\section{Discussion}

The ovotestis structure of $S$. atricauda follows the type of organization that is typical of Serranidae family and which is also found in other species of Serranus inhabiting the Eastern Atlantic and Mediterranean: S. cabrilla 
Fig. 3 Serranus atricauda percentage of different ovarian (a) and testicular (b) maturation phases through the sampling period. Sampled individuals per month are given in brackets

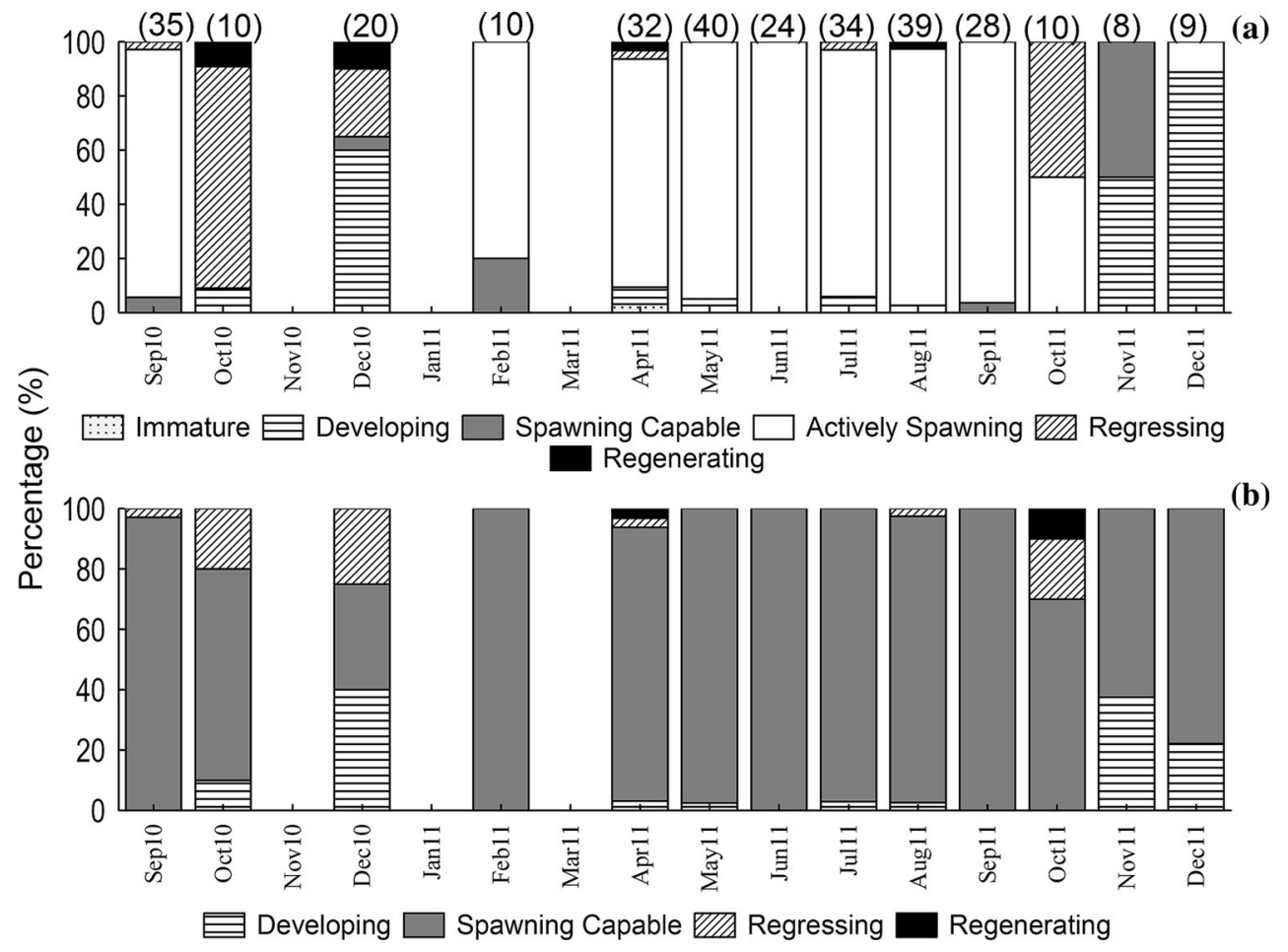

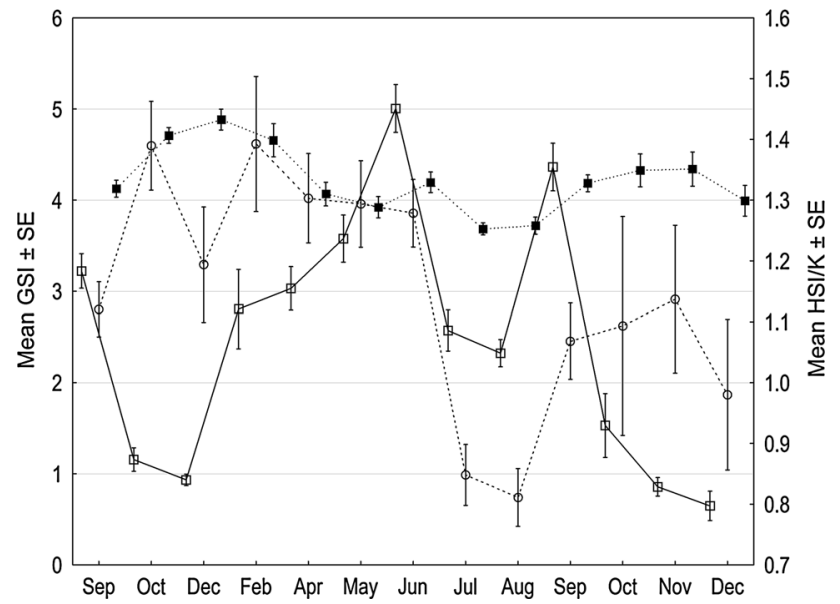

Fig. 4 Monthly variation of the mean and standard error of gonadosomatic index (GSI, empty squares), hepatosomatic index (HSI, empty circles) and Fulton's condition factor ( $K$, black squares) for Serranus atricauda (sampled individuals per month are as shown in Fig. 3)

(García-Díaz et al. 1997); S. scriba (Tuset et al. 2005; Alonso-Fernández et al. 2011) and S. hepatus (Bruslé 1983). The similarities found in these four species were highlighted by Erisman and Hastings (2011) where these species form a group within the Serranus clade in the phylogenetic hypothesis tree obtained in their reproductive evolution study.

The length range sampled in our study was biased towards large individuals with an absence of small ones.
This was probably due to the fact that the target species in the Portuguese fishery is not the blacktail comber, but the Atlantic wreckfish (Polyprion americanus) and large hooks are used in the longline fishery. Therefore, small individuals which live in shallower waters (Tuset et al. 2004) and feed mainly on benthic species (Morato et al. 2000) are not caught. The absence of these small individuals made it impossible to estimate other reproductive parameters like the maturity ogive and length at $50 \%$ maturity.

Spawning capable individuals were present throughout the year, with a first GSI peak in June and a second and smaller one in September and an extended spawning season was also reported for the species in Canary Islands (García-Díaz et al. 2006).

It is known that prolonged spawning seasons are typical of indeterminate fecundity species (e.g. Merluccius merluccius (Murua et al. 2006), Sardina pilchardus (Zwolinski et al. 2001), Thunnus albacares (Schaefer 1996), Trachurus trachurus (Gordo et al. 2008) and that reproduction success of these species is highly influenced by environmental conditions (e.g. temperature and food availability) during the spawning period (Hunter and Leong 1981). Therefore, the rich fauna and flora inhabiting the seamounts (Morato and Clark 2007; Samadi et al. 2007) can also justify this wide spawning season. The highest values of $K$ and HSI observed during the months before spawning may suggest that fish condition may play an important role in the onset of reproduction, although, in indeterminate fecundity species, feeding conditions will greatly influence 
Fig. 5 Serranus atricauda oocyte size-frequency distribution per $50-\mu \mathrm{m}$-diameter class through the spawning period
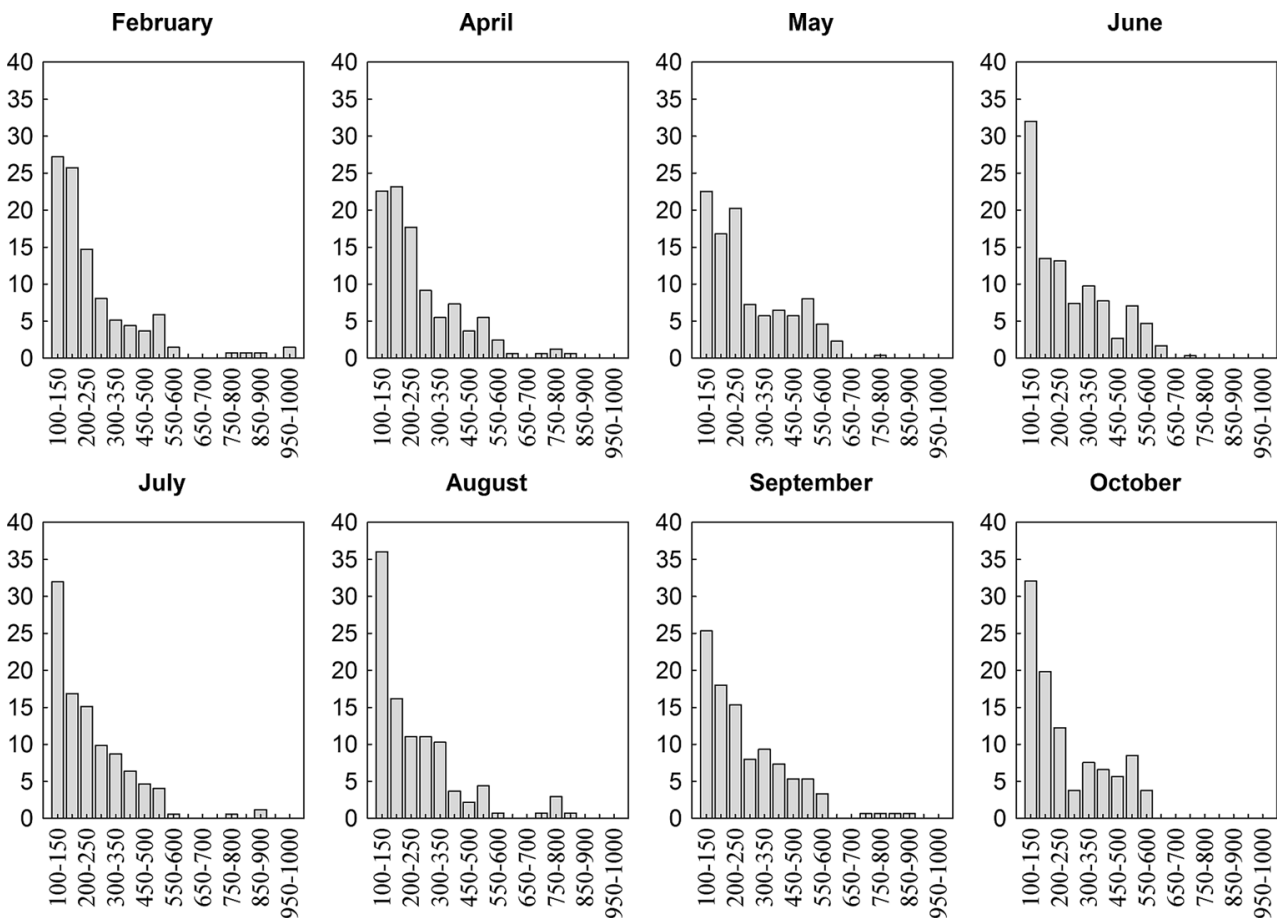

September
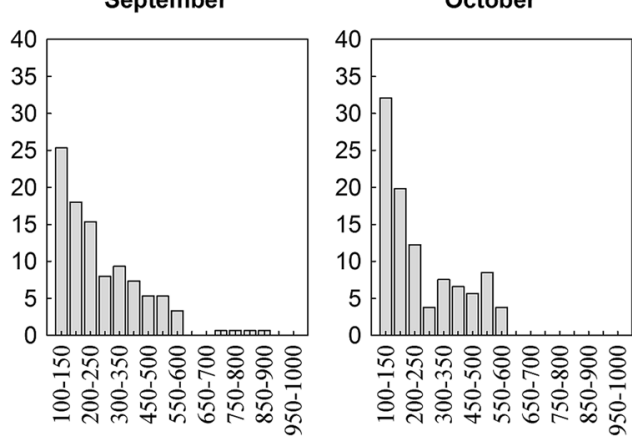

Oocyte diameter $(\mu \mathrm{m})$

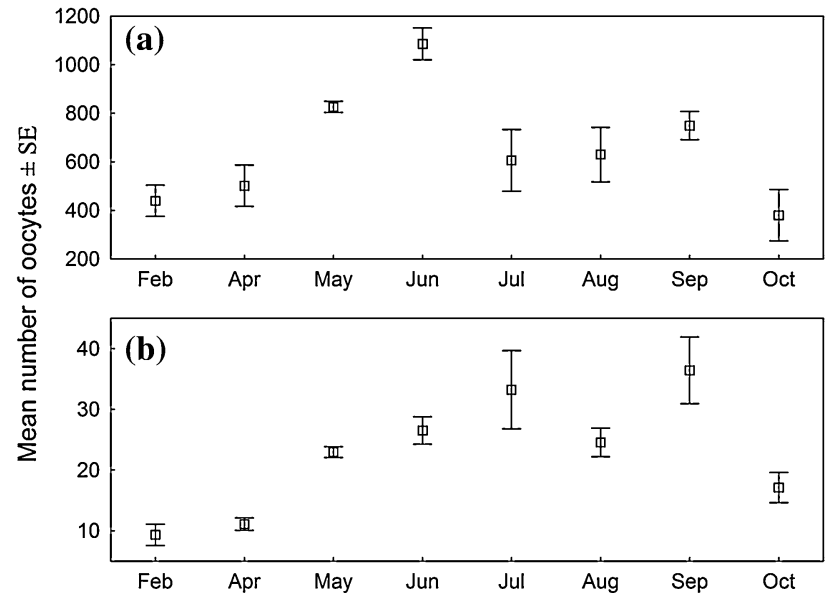

Fig. 6 Monthly variation of the mean and standard error of the number of secondary growth oocytes (a) and advanced oocytes (b) per gram of gutted weight through the spawning season

spawning activity and the rate of recruitment of pre-vitellogenic oocytes into the stock of yolked ooyctes (Rinchard and Kestenmont 2003).

In this study, all lines of evidence to access fecundity type were analysed for the first time and it was concluded that $S$. atricauda exhibits indeterminate fecundity: there was no size gap between the primary and secondary growth oocytes and the mean diameter of SG oocytes did not increase over the spawning season since there was no dominant oocyte size class progressing through time. Further, the number of advanced oocytes showed no decline

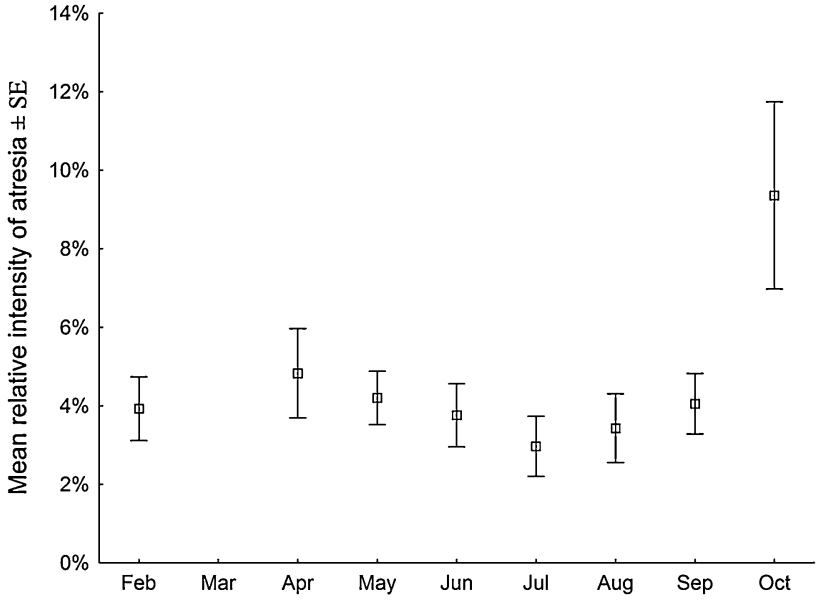

Fig. 7 Monthly variation of the mean and standard error of relative intensity of atresia through the spawning period for Serranus atricauda

with progressing spawning season. In fact, the pattern observed in our study showed an increase trend along the spawning season and a sharp decrease at the end, which can indicate that this species initiate spawning with a mild effort which increases along the season possibly as the environmental conditions improve. However, a further specific investigation including several spawning seasons is required to confirm this.

In this work, spawning frequency was accessed by the frequency of actively spawning females in the mature active population. Probably, the most used method to 
Fig. 8 Relationship of absolute batch fecundity with total length and gutted weight for Serranus atricauda

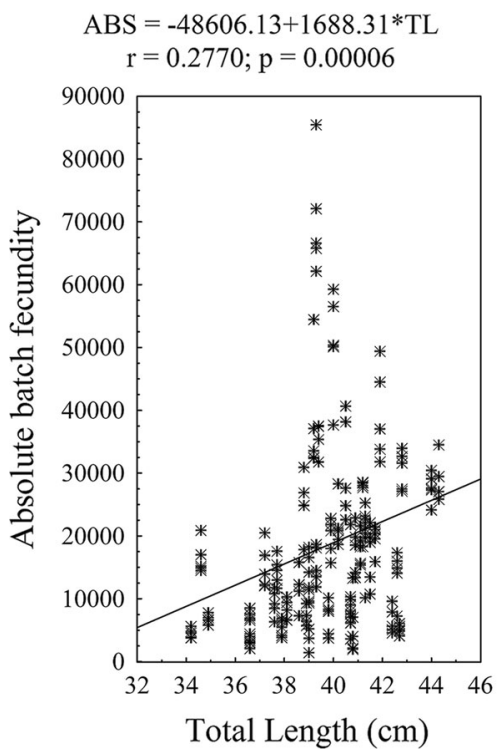

estimate the spawning fraction is based on the POF deterioration stage information. However, in most species, this information is not available and another approach has been employed for other species with indeterminate fecundity that corresponds to the actively spawning stage (e.g. Trachurus trachurus Gonçalves et al. 2009; Trisopterus luscus Alonso-Fernández et al. 2011). The reason for the appliance of this methodology relies on the fact that late migratory-nucleus stage oocytes and hydrated oocytes are expected to be spawned in a short time period (between 12 and $24 \mathrm{~h}$ ) (Karlou-Riga and Economidis 1997; AlonsoFernández et al. 2011; Ganias et al. 2011) and it is also a short time-consuming method. In our study, spawning occurred daily in contrast to the 3.8 days estimated by García-Díaz et al. (2006). This difference in the spawning frequency may rely on geographical, ecological and behavioural differences as happens in other species like the sardine, Sardina pilchardus and horse mackerel, Trachurus trachurus. For this species, Gonçalves et al. (2009) reported spawning frequency from 4.9 to 13.2 days in different months of spawning season for the Iberian coast stock while for Greek waters, Karlou-Riga and Economidis (1997) mentioned values of 5.8 and 4.8 for two successive reproductive periods. In fact, and according to these authors, spawning frequency may change from year to year and therefore might be another adaptive response to unfavourable conditions occurring within the spawning season. Furthermore, in a recent review paper on size- and agedependence in batch spawning, Fitzhugh et al. (2012) reported a positive relation between spawning frequency with age or size for several species.

Regarding the spawning frequency reported in this paper, it is worthwhile to mention that Alonso-Fernández et al. (2011) also found a daily spawning frequency for
S. scriba in the Balearic Islands, a species of the same genus. The low variability showed by this parameter along the spawning season (estimates varied between 1 and 1.25) and the significant number of individuals obtained for the majority of the months make us believe that $S$. atricauda spawns daily in the studied seamounts.

The estimated relative batch fecundity $(22 \pm 17$ oocytes per gram of individual) is low when compared to other indeterminate species such as Trachurus trachurus (Gonçalves et al. 2009), Engraulis mordax (Hunter et al. 1985), Merluccius merluccius (Murua et al. 2006), Sardina pilchardus (Zwolinski et al. 2001) and even with the same species living in the waters of the Canary Islands (GarcíaDíaz et al. 2006). However, the prolonged spawning season and the short interval between batches may compensate for the comparatively low batch fecundity.

Our study provides preliminary information for a species which has increased catches since 2005 (DGRM 2012), and no fishing measures have been established to assure a healthy condition of this population, moreover when this fishery is being carried out in a new exploited ecosystem, the south-west Portugal seamounts, from where poor to no information is available. In this way, a future thorough study would be recommended to better clarify not only other $S$. atricauda reproduction aspects (e.g. bioenergetics dynamics of reproduction, annual variation of fecundity) but also estimate key population parameters to determine the population status and productivity.

The present work confirms that $S$. atricauda is a synchronously hermaphroditic species with an asynchronous oocyte growth and has, definitely, an indeterminate fecundity type, which is for the first time studied in detail based on several accepted criteria (Hunter et al. 1992; Greer Walker et al. 1994; Murua and Saborido-Rey 2003). 
The knowledge of the type of fecundity contributes to a better understanding of the reproductive potential and allows relative annual fecundity estimation. The estimated relative fecundity was low when compared to other indeterminate species.

As already highlighted by Zudaire et al. (2013), this kind of thorough study of fecundity type is required in particular for application of the daily egg production method (DPEM) which would provide a fishery-independent estimation of the spawning stock biomass.

Acknowledgments This study was partially supported by the PROMAR project 31-03-05-FEP-8 "Planos de gestão e medidas de minimização de capturas acessórias e rejeições na pescaria de palangre do banco Gorringe". Ana Rita Vieira, Rafaela Barros Paiva and Vera Sequeira were funded by grants from the Fundação para a Ciência e a Tecnologia: SFRH/BD/73506/2010, SFRH/BD/80268/ 2011 and SFRH/BPD/70200/2010.

\section{References}

Alonso-Fernández A, Dominguez-Petit R, Bao M, Rivas C, SaboridoRey F (2008) Spawning pattern and reproductive strategy of female pouting Trisopterus luscus (Gadidae) on the Galician shelf of north-western Spain. Aquat Living Resour 21:383-393

Alonso-Fernández A, Alos J, Grau A, Dominguez-Petit R, SaboridoRey F (2011) The use of histological techniques to study the reproductive biology of the hermaphroditic Mediterranean fishes Coris julis, Serranus scriba, and Diplodus annularis. Mar Coast Fish Dyn Manage Ecosyst Sci [online serial] 3:145-159

Brown-Peterson NJ, Wyanski DM, Saborido-Rey F, Macewicz BJ, Lowerre-Barbieri SK (2011) A standardized terminology for describing reproductive development in fishes. Mar Coast Fish Dyn Manage Ecosyst Sci 3:52-70

Brusle S (1983) Contribution to the sexuality of a Hermaphroditic teleost, Serranus hepatus L. J Fish Biol 22:283-292. doi:10. 1111/j.1095-8649.1983.tb04752.x

DGRM (2012) Recursos da pesca—série estatística. DGRM, Lisbon (In Portuguese)

Emerson LS, Greer Walker M, Witthames PR (1990) A stereological method for estimating fish fecundity. J Fish Biol 36:721-730

Erisman BE, Hastings PA (2011) Evolutionary transitions in the sexual patterns of fishes: insights from a phylogenetic analysis of the Seabasses (Teleostei: Serranidae). Copeia 2011:357-364

Fishelson L (1992) Comparative gonad morphology and sexuality of the Muraenidae (Pisces, Teleostei). Copeia 1992:197-209

Fitzhugh GR, Shertzer KW, Kellison GT, Wyanski DM (2012) Review of size and age dependence in batch spawning: implications for stock assessment of fish species exhibiting indeterminate fecundity. Fish Bull 110:413-425

Ganias K (2013) Determining the indeterminate: evolving concepts and methods on the assessment of the fecundity pattern of fishes. Fish Res 138:23-30

Ganias K, Nunes C, Vavalidis T, Rakka M, Stratoudakis Y (2011) Estimating oocyte growth rate and its potential relationship to spawning frequency in teleosts with indeterminate fecundity. Mar Cost Fish 3:119-126

García-Díaz MM, Tuset VM, González JA, Socorro J (1997) Sex and reproductive aspects in Serranus cabrilla (Osteichthyes: Serranidae): macroscopic and histological approaches. Mar Biol $127: 379-386$
García-Díaz MM, Lorente MJ, González JA, Tuset VM (2002) Morphology of the ovotestis of Serranus atricauda (Teleostei, Serranidae). Aquat Sci 64:87-96

García-Díaz M, González JA, Lorente MJ, Tuset VM (2006) Spawning season, maturity sizes, and fecundity in blacktail comber (Serranus atricauda) (Serranidae) from the easterncentral Atlantic. Fish Bull 104:159-166

Gonçalves P, Costa AM, Murta AG (2009) Estimates of batch fecundity, and spawning fraction for the southern stock of horse mackerel (Trachurus trachurus) in ICES Division IXa. ICES J Mar Sci 66:617-622

Gordo LS, Costa A, Abaunza P, Lucio P, Eltink ATGW, Figueiredo I (2008) Determinate versus indeterminate fecundity in horse mackerel. Fish Res 89:181-185

Grande M, Murua H, Zudaire I, Korta M (2012) Oocyte development and fecundity type of the skipjack, Katsuwonus pelamis, in the Western Indian Ocean Source. J Sea Res 73:117-125

Greer Walker M, Witthames PR, Bautista de los Santos I (1994) Is the fecundity of the Atlantic mackerel (Scomber scombrus: Scombridae) determinate? Sarsia 79:13-26

Grier HJ (1981) Cellular organization of the testis and spermatogenesis in fishes. Am Zool 21:345-357

Hilborn R, Walters CJ (1992) Quantitative fisheries stock assessment: choice, dynamics and uncertainty. Chapman \& Hall, New York

Hunter JR, Leong R (1981) The spawning energetics of female northern anchovy, Engraulis mordax. Fish Bull 79:215-229

Hunter JR, Lo NCH, Leong RJH (1985) Batch fecundity in multiple spawning fishes. In: Reuben L (ed) An egg production method for estimating spawning biomass of pelagic fish: Application to the northern anchovy, Engraulis mordax. U.S. Department of Commerce, NOAA Technical Report NMFS-36, pp 67-77

Hunter JR, Macewicz BJ, Lo NCH, Kimbrel CA (1992) Fecundity, spawning, and maturity of female Dover Sole, Microstomus pacificus, with an evaluation of assumptions and precision. Fish Bull 90:101-128

Karlou-Riga C, Economidis PS (1997) Spawning frequency and batch fecundity of horse mackerel, Trachurus trachurus (L.), in the Saronikos Gulf (Greece). J Appl Ichthyol 3:97-104

Morato T, Clark MR (2007) Seamount fishes: ecology and life histories. In: Pitcher TJ, Morato T, Hart PJB, Clark M, Haggan N, Santos RS (eds) Seamounts: ecology, fisheries and conservation. Blackwell Publishing, Oxford, pp 170-188

Morato T, Santos RS, Andrade JP (2000) Feeding habits, seasonal and ontogenic diet shift of blacktail comber, Serranus atricauda (Pisces: Serranidae), from the Azores, north-eastern Atlantic. Fish Res 49:51-59

Murua H, Motos L (2006) Reproductive strategy and spawning activity of the European hake Merlucius merlucius (L.) in the Bay of Biscay. J Fish Biol 69:1288-1303

Murua H, Saborido-Rey F (2003) Female reproductive strategies of marine fish species of the North Atlantic. J Northw Atl Fish Sci 33:23-31

Murua H, Kraus G, Saborido-Rey F, Witthames PR, Thorsen A, Junquera S (2003) Procedures to estimate fecundity of marine fish species in relation to their reproductive strategy. J Northw Atl Fish Sci 33:33-54

Murua H, Lucio P, Santurtún M, Motos L (2006) Seasonal variation in egg production and batch fecundity of European hake Merluccius merluccius (L.) in the Bay of Biscay. J Fish Biol 69:1304-1316. doi:10.1111/j.1095-8649.2006.01209.x

Puebla O, Bermingham E, Guichard F (2011) Perspective: matching, mate choice, and speciation. Integr Comp Biol 51:485-491. doi:10.1093/icb/icr025

Rinchard J, Kestenmont R (2003) Liver changes related to oocyte growth in roach a single spawner fish, and in bleak and white bream, two multiple spawner fish. Int Rev Hydrobiol 88:68-76 
Saborido-Rey F, Murua H (2003) Female reproductive strategies of marine fish species of the North Atlantic. J Northw Atl Fish Sci 33:23-31

Samadi S, Schlacher T, de Forges BR (2007) Seamount benthos. In: Pitcher TJ, Morato T, Hart PJB, Clark M, Haggan N, Santos RS (eds) Seamounts: ecology, fisheries and conservation. Blackwell Publishing, Oxford, pp 119-140

Schaefer KM (1996) Spawning time, frequency, and batch fecundity of yellowfin tuna Thunnus albacares, near Clipperton Atoll in the eastern Pacific Ocean. Fish Bull 94:98-112

Selman K, Wallace RA (1986) Gametogenesis in Fundulus heteroclitus. Am Zool 26:173-192

Tortonese E (1986) Serranidae. In: Whitehead PJP, Bauchot M-L, Hureau J-C, Nielsen J, Tortonese E (eds) Fishes of the Northeastern Atlantic and the Mediterranean. FAO, Rome, pp 780-792

Tuset VM, González JA, Lozano IJ, García-Díaz MM (2004) Age and growth of the blacktail comber, Serranus atricauda (Serranidae), off the Canary Islands (centraleastern Atlantic). Bull Mar Sci 74:53-68

Tuset VM, Garcia-Diaz MM, Gonzalez JA, Lorente MJ, Lozano IJ (2005) Reproduction and growth of the painted comber Serranus scriba (Serranidae) of the Marine Reserve of Lanzarote Island (central-eastern Atlantic). Est Coast Shelf Sci 64:335-346

Tyler CR, Sumpter JP (1996) Oocyte growth and development in teleosts. Rev Fish Biol Fish 6:287-318

Wallace AR, Selman K (1981) Cellular and dynamic aspects of oocyte growth in teleosts. Am Zool 21:325-343

Zudaire I, Murua H, Grande M, Korta M, Arrizabalaga H, Areso JJ, Delgado-Molina A (2013) Fecundity regulation strategy of the yellowfin tuna (Thunnus albacares) in the Western Indian Ocean. Fish Res 138:80-88

Zwolinski J, Stratoudakis Y, Soares E (2001) Intra-annual variation in the batch fecundity of sardine off Portugal. J Fish Biol 58:1633-1645 